\title{
BUSINESS KNOWLEDGE MANAGEMENT AS A PREREQUISITE FOR A STRONGER POSITION IN THE MARKET
}

\author{
Gazmend DEDA $^{1 *}$, Arben TËRSTENA ${ }^{2}$ \\ ${ }^{1 *}$ University of Applied Sciences in Ferizaj, Kosovo; \\ ${ }^{2}$ University of Applied Sciences in Ferizaj, Kosovo; \\ *Corresponding author Gazmend DEDA, e-mail: gazmend.deda@ushaf.net;
}

Received March 2019; Accepted April 2019; Published July 2019;

DOI: https://doi.org/10.31407/ijees9313

\begin{abstract}
Companies are realizing how important it is to "know what they know" and to be able to use their knowledge to the maximum. This knowledge is encountered in many countries such as databases, knowledge bases, data cabinets and people's heads, and they are distributed throughout the companies. It also happens that a part of company repeats the other company's work, simply because it is impossible to pursue and utilize knowledge in other parts. Companies should know:

$\checkmark \quad$ Which are their means of knowledge;

$\checkmark$ How to manage and use these tools to achieve the maximum return (profit).

The company's most traditional policies and controls focus on its most available tools by letting unmanaged the most important tools, the knowledge ones. Success in markets where competition tends to grow depends on the quality of knowledge used by organizations in key business processes. For example, the bidding partdepends on the knowledge in various fields, including raw material, planning, production and distribution. Product development also requires knowledge about consumer requirements, new scientific developments, new technology developments, marketing, and so on. The issue of organizing the means of knowledge of an organization to create competitive advantage becomes more important when:

$\checkmark$ Markets are increasingly competitive and innovation rates are increasing so that knowledge has to develop and adopt at a very rapid growth rate.

$\checkmark$ Corporations organize their businesses to be focused on creating customer values. Staff functions have been reduced in line with management structures. There is a need in changing the informal management of staff function knowledge with formal methods in customer directed business processes.

$\checkmark$ Competition is reducing the size of the workforce that holds this knowledge.

$\checkmark \quad$ Knowledge takes time for experience and development. Employees have less and less time to do so.

$\checkmark$ There is a tendency for employees to retire earlier and increase mobility, which leads to loss of knowledge.

$\checkmark \quad$ There is a need for managing complexity as small business operators and transnational resource operations.

The change in strategic direction can result in loss of knowledge in a particular field. A future change in politics may lead to a renovated request for this knowledge, but employees with this knowledge may not be there.
\end{abstract}

Key words: business knowledge management, stronger position, market 


\section{INTRODUCTION}

\section{Knowledge as The Basic Source of Business Companies in the $21^{\text {st }}$ Century}

\section{Definition of knowledge, types, and division}

Several years ago, technologies such as intranet Lotus Notes, and MS-exchange were considered as potential knowledge managers. The modern interest (IRI) of these technologies is related to portal knowledge, intelligent agent, and push-based technologies. Even with the fantastic technological advances and the holding of company investments in such technologies, many "organizations" still try to find answers to some simple questions about how to make, sell and transfer knowledge and enable employees share their wisdom. Tracks for answering such questions have become imperative for organizations to clearly understand the strategy and difference between knowledge and information. This strategic distinction is not semantic; first it is a critical implication of leadership and survival in the economy. While the media and net executives will compete for "EYE-BALLS" and Mindshare, "and virtual companion understands it in the new E-business world, the deficit source will not be the information, but the care of the people.

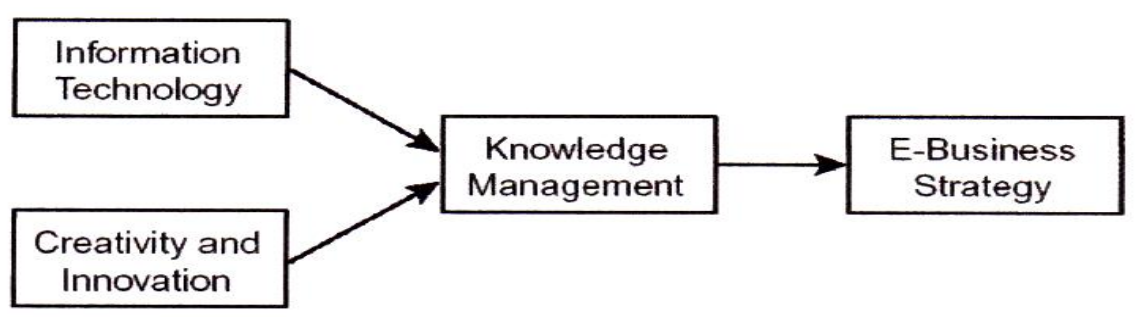

Figure 1. Knowledge Management and E-Business Strategy

Based on these arguments, it is obvious that the important human care, innovation, and creativity to improve archived knowledge, creativity of new knowledge, and innovative knowledge applications are new products and services that create a market built. In the context of the opportunities of E-business strategies, the presentation of the concept of knowledge management is given in fig. 1.

According to the scheme given, the working definition of knowledge management has been shown. Knowledge Management provides critical scenarios of organizational adaptations, survival and competition with the confrontation of growing discontentional changes in a region. Unlike many concepts of knowledge management presented in the information system research in the media, the first concept is better in relation to the new model of business strategies in the innovative model. With rapid technological feedback, we will have great choice in technology terms that can ease E-Business specific strategy, such as managing customer relationships, managing value chains, or managing a sales chain.

Recently in local written media but also on television, during debates on various economic issues, phrases of knowledge and knowledge management can often be read or heard, and the role of knowledge in solving possible economic problems is increasingly emphasized. The same thing is on scientific meetings; topics related to contemporary management and the handling of economic subjects' survival issues in unsafe business environments. Also, concepts of intellectual capital and business intelligence are present. At the same time, more and more is being discussed about the transition from the information society to the knowledge society. During this, the notion of knowledge is rarely defined, while the concept of knowledge management back to 90 s was quite popular and highly elaborated in foreign literature as one of the "tools" available for contemporary management in everyday practice.

Emphasizing the role of knowledge recently is a result of significant structural changes in emerging economies. It has changed completely in the last century and the transition from the industrial economy to a moderneconomy, the main resources are no longer material goods, but the new factor of activity and productivity becomes the knowledge economy.

During the Industrial Revolution, human knowledge has been adapted to the work of machines, existing processes and products, while the primary role of knowledge was to increase the productivity of human labor. The main 
industrial economy leaders represented large corporations and mass production that easily found buyers in the market. The business policy focused on increasing the volume of production which meant the installation of the largest quantity of materials in the products. But today, when the offer significantly exceeds the demand (according to some reports up to $30 \%$ ), production growth is focused on increasing the amount of information and knowledge in order to increase efficiency in terms of quality production. The highest added value in a product derives from knowledge rather than from materials introduced into the product. Examples of this are today automobiles, the value of which increases depending on the number modern technological inventions they have. The consequence of which is the increasing sales of intelligence and not of raw materials. Business subjects have reached the point that they have to change their bussines behaviours. Ruthless competition forces them to use their main business resources as best they can, and these are mostly the information and knowledge that their employees possess.

The shift from the industrial economy to the knowledge economy is characterized by several important steps: information becomes an important resource and communication and information technology becomes a fundamental infrastructure. With the development of these technologies, business becomes much faster and then to shortening production and business cycles. And much more important, the ratio to production today varies in favor of demand, namely of customers. In fact, final buyers and users today are the main factors that set the conditions, so only quality products have a chance in the market. For this reason, the need for constant creation of new knowledge is imposed on firms, mainly by investing in their employees. Creating intellectual potential creates a new competitive weapon of the new economy where knowledge is the main product. In such an environment where raw material or material is less important, and "intelligence" is increasingly sold, knowledge becomes a basic necessity of life. So the global world market focuses on demand, creation and preservation of knowledge. Knowledge is not only stored on documents or bases of knowledge but is always becoming part of organizational processes and organizational culture. The importance of knowledge is oriented toward business management, so it can be said about knowledge management as one of the essential business functions.

The notion knowledge itself can be defined as a material resource, reality that expresses the human ideas while looking at the world around it: space, object, reports, and events in that reality. It consists of intuitions, group ideas, experiences, skills and learning and has the potential to create new values. Knowledge is created in people's mind. According to the author, who was the first to deal with issues of knowledge creation and exploitation, Michael Polany1, knowledge can be divided into explicit knowledge and calm knowledge or experience.

Explicit knowledge is articulated with formal language and can be easily transmitted in the form of information from individual to individual. This, for example, is stored in books and can easily be "learnt" in the education process, during the use, and taken and applied to products in forms of standard technical specifications, projects or standardized designs. Contrary to this, knowledge of silence or experience is the knowledge implemented or created by the personal experience of the individual and includes intact factors, such as personal confidence, instinct, personal values, and acquired skills. It is personalized and is not easy to reach, and often remains undetected and unused. This form of knowledge is richer than the general one however, it has no value if it is not used. Looking at the firm's prospect, the knowledge of the experience of all its employees is not easy to gather, share, or exploit. However, this type of knowledge is of great value if used and this usually brings new values to the firm and represents an important element of competitive advantage.

Although knowledge is a non-material resource, it can be collected, stored and transmitted by text, speech, and photographs. Although it is out of the media it can be created and transmitted using the same or with the combination of different media.

By explaining the notion of knowledge, within the framework of this paper which emphasizes business interests, knowledge can be related to human and organization, and its realization in the organization is done through the creation of a knowledge management system. Today, in the modern business world, there is a developed conscience that general knowledge in the organization is far greater than it is used in the organization's processes. In this dispute, Lew Platt, former Hewlett Packard executive director says: "If HP knew what HP knows, we would be three times more profitable"2

In general, knowledge exists in people and in teams and is the general organizational knowledge and potential that can be measured. It represents the intellectual capital of a firm and is part of the overall value of the firm. In the case of individuals leaving the enterprise, knowledge is lost due to lack of documentation. The same thing happens with

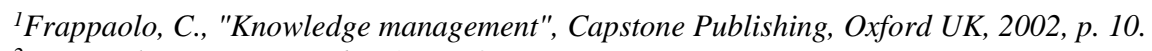

${ }^{2}$ Frappaolo, C., cit. named in 1., pg. 2. 
the knowledge of the teams which is usually not documented and exchanged with learning to increase the competence of the firm. In the context of organizational knowledge, explicit knowledge is viewed as information because of business opportunities, it is easier to collect and broadcast through computer technology. On the other hand, the transfer of knowledge with experience or quiet knowledge is carried out through personal communication. In last decade, the main interest of organizations has been the investment on IT technologies, which usually focus on explicit knowledge, because it is easier to gather, manage, and determinethe quality and much easier to transfer. On the other hand, it can be ascertain that there is still a general mistrust of anything that cannot be objectively followed and which cannot be determined, which is also the case with the knowledge of the experience.

But what sets the distinction between an organization and what makes it successful can be related to the knowledge of the experience that the relevant organization possesses. The problem arises because the knowledge of experience is constantly changing; it changes, grows with new skills learned and new owner experiences and is difficult to be"caught" and registered. The ability of the organization to expand the level of knowledge from experience and to share that knowledge with its employees is perceived as a basic task of knowledge management functions. We can ascertain that there is still no way that will be fully able to manage knowledge from experience, but some of this knowledge can be "included" by an individual in the organization, using the appropriate tools and techniques to identify and set the amount in order to be available to others in the organization. With the process mentioned, a part of knowledge in an organzitationcan create a third kind of knowledge, so-called implicit knowledge. The implicit knowledge feature is that it is specific to a particular firm and is difficult to duplicate. As mentioned, it is created within the firm, or is accumulated as knowledge of successful solutions and ways of managing managerial problems, and this represents an important element in the competitive advantage for that firm.

In addition to the above classification, knowledge by substance can be divided into factual knowledge, procedural knowledge and judgmental knowledge. ${ }^{3}$ Judicial knowledge is made up of information and data, procedural sciences represent techniques such as algorithmic and heuristic procedures and are used in experimental systemsor by experts to solve specific problems. Judicial knowledge enables reviewing and evaluating constraints and is essential for management in the planning process to realize the planned objectives. Figure 1 shows the scheme of the basic knowledge of the composition.

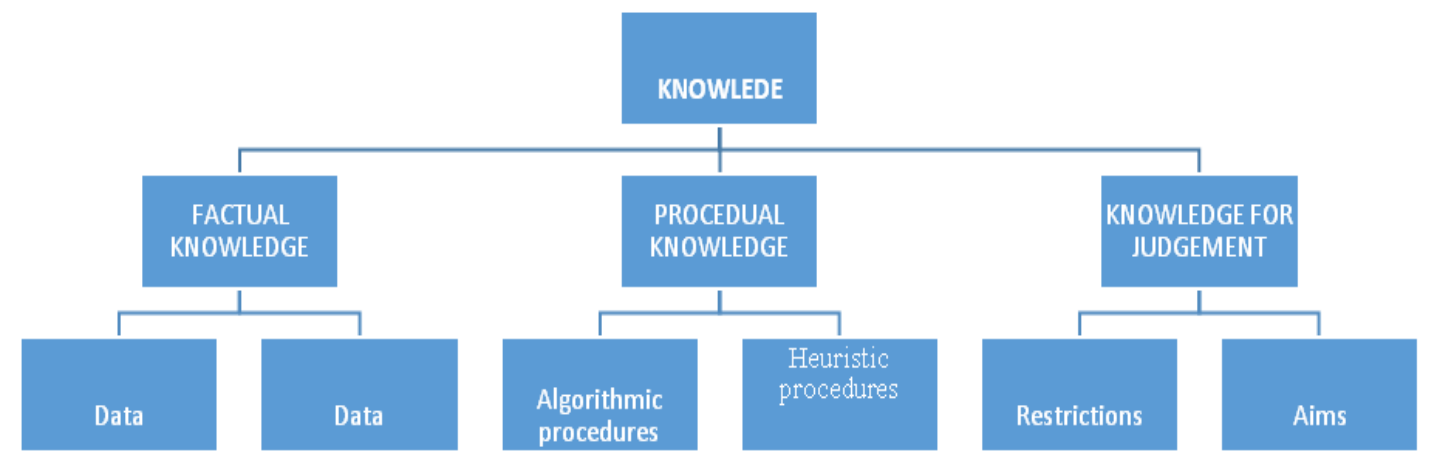

Figure 2. The schematic overview of knowledge classification Bearers of knowledges

Knowledge consists of facts, rules, methodologies, theories, examples, etc. Models represent the bearers of knowledge. They appear when the image of the reality surrounding us is expressed by the ideas of the individual who looks at the world around himself. When an individual picture created by an individual is more appropriate to be understood than others, it becomes a model of reality and is taken from the previous source of knowledge. The taken photograph may be the same or similar to reality, so that similarity becomes a measure for measuring the quality of knowledge. This process of modeling and transferring knowledge is the starting point for all the elements of the knowledge process. Bearers of knowledge form the basis of knowledge management construction systems. According to the knowledge sources, when it comes to organazing, the bearer of knowledge includes organizational knowledge, explicit knowledge and knowledge of individual experience, knowledge of technologies (applications, computers, networks) and knowledge from external sources.

\footnotetext{
${ }^{3}$ Vidović, S., "Upravljanje znanjem", InfoTrend, Zagreb, Nr. 107, 2003., f. $44 .-47$.
} 


\section{MATERIAL AND METHODS}

\section{Knowledge Management Process}

The introduction notes the importance of knowledge about business management. Nowadays, in the modern economy the most important resource is considered human knowledge, so the knowledge management is a necessry component of contemporary management.

If we want to define the notion itself, in terms of business management, we can say that knowledge management is a process that has to do with identifying-setting knowledge, organizing, saving and distributing knowledge and the experience of individual groups within the organization 4 . The overall management objective is to connect those who need knowledge with the sources of knowledge in the organization and coordinate the transfer of that knowledge. The concrete purpose of knowledge management, however, represents a process of identifying and analyzing the knowledge available to meet the objectives set by the business organization.

Further, knowledge management involves a continuous process of knowledge renewal in the organization and also in its essence differs from other approaches, for example, reengineering business processes or overall quality management.

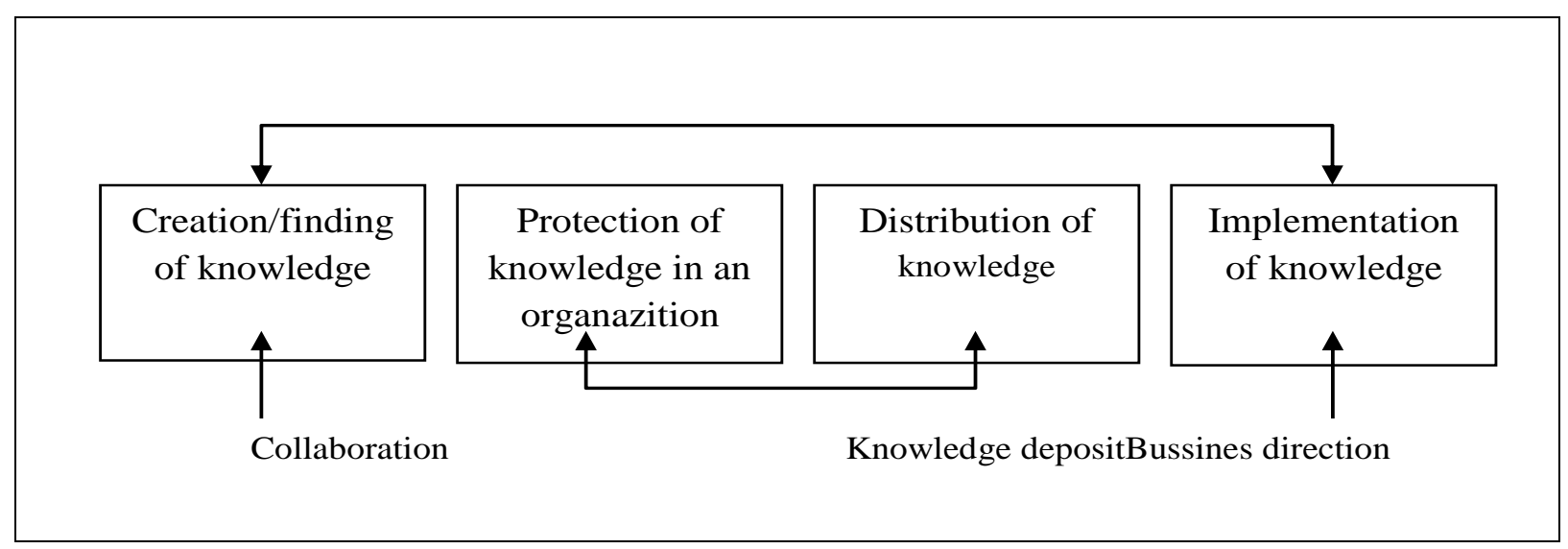

Figure 3. The key stages of the knowledge management process

Reengineering is an activity that is intended to choose any problems presented at a determined time, the purpose of the knowledge management process is to innovate and continually modify knowledge so that the organization is able to keep pace with the dynamic market environment. The knowledge management process consists of some following elements: finding / knowledge creation, knowledge protection, knowledge exchange and finally knowledge implementation. An organization which aims at the continuous renewal of knowledge is called "Learning organization" this process is continuous and cyclic. Figure 3 shows the key stages in the knowledge management process.

\section{RESULTS}

\section{Knowledge Chain}

For the successful development of knowledge management processes in an organization it is important to understand the concept with the help of which a range of important interactions has been shown in the creation of an innovative organizational knowledge cycle, the verse of knowledge, known in English as Knowledge chain, which was

${ }^{4}$ www.netlingo.com/right.cfm?term $=$ KM, "NetLingo Dictionary of Internet Words", 04.03.2003. 
introduced by the authors Koulopoulos, Toms and Spinello in their study book "Corporate Instinct". The chain contains four elements that form the essence of management's usefulness with knowledge. They are internal organization awareness, internal reactivity, internal awarness, external awarness, and external reactivity.

The organization's internal awareness represents the ability to quickly evaluate its key competence and overall skills. The problem may arise in those organizations whose activity is carried out according to the rules set within the framework of the functional structure.

Their basic competence is related to existing products or services, while not understanding at the same time the importance of knowledge, skills and personal skills that are important for their further development. They focus themselves on existing products, what they have done before, which means in the past and not what they are capable of doing.

The other element in the knowledge chain is related to internal reactivity. Internal reactivity is reflected in the ability of the organization to utilize its knowledge and key competencies so that it can quickly implement it in the new product or service and provide customers with the market. In practice, it happens that organizations are aware of the situation in the external environment but are not yet able to react immediately to changes and external environment requirements, that is, to start with the use of knowledge and skills that possess them.

External awarenessand conscious of the environment around the organization represents its ability to accurately assess the position of its products or services on the market, and in time to observe the new trends in the market as well as the desires and habits of consumers identify the risks that threaten their activity by competitors, take care of institutional obligations, new legal norms, etc. And most importantly, with traditional market research activities have the ability to timely evaluate future market demands.

Table 1. Activities in the organization related to the individual elements of the chain

\begin{tabular}{|c|c|}
\hline INTERNAL & EXTERNAL \\
\hline \multicolumn{2}{|l|}{ Organization that constantly "learns" } \\
\hline $\begin{array}{l}\text { Collective conscience of power and } \\
\text { disadvantages within functional structures, } \\
\text { experiences are openly transferred, focus is on } \\
\text { competencies and talents rather than products. }\end{array}$ & $\begin{array}{l}\text { Thinks ahead of potential competition, it constantly } \\
\text { removes obstacles and explores innovative } \\
\text { approaches to finding new customers. }\end{array}$ \\
\hline \multicolumn{2}{|l|}{ Traditional organization } \\
\hline $\begin{array}{l}\text { Poor internal conscience is guided by the } \\
\text { hierarchical structure of functional, political } \\
\text { and static structure, knowledge is not } \\
\text { distributed, focus is on existing production }\end{array}$ & $\begin{array}{l}\text { It relies on existing brands, not paying much } \\
\text { attention to exploring new opportunities to keep } \\
\text { existing benefits and new customers, too little } \\
\text { devotion to forecasting movements in the market. }\end{array}$ \\
\hline INTERNAL & EXTERNAL \\
\hline \multicolumn{2}{|l|}{ Organization that constantly "learns" } \\
\hline $\begin{array}{l}\text { It is able to immediately use all of its } \\
\text { capabilities based on internal assessment of its } \\
\text { own resources and assessment of new } \\
\text { requirements and market opportunities. }\end{array}$ & $\begin{array}{l}\text { Focus on new products / services for buyers, which } \\
\text { are the result of their knowledge and added value of } \\
\text { products, even though the market has still articulated } \\
\text { and the return on investment is unsafe. }\end{array}$ \\
\hline \multicolumn{2}{|l|}{ Traditional rganization } \\
\hline $\begin{array}{l}\text { The new ideas are "overwhelmed" because of } \\
\text { the support in the new established procedures } \\
\text { and the strict hierarchical decision-making style } \\
\text { within the rigid organizational structure. }\end{array}$ & $\begin{array}{l}\text { Other products between innovative cycles, } \\
\text { underdeveloped distribution channels with standard } \\
\text { products. }\end{array}$ \\
\hline
\end{tabular}

External reactivity can be characterized as an organization's ability to adapt market demands faster and more efficiently than its competitors. This ability is also the essence of competitive advantage and the issue of survival in the market.

Table 1 presents the chain of knowledge elements with the activities that take place in two types of organizations, in those who accept the concept of knowledge management, the so-called "learning" and the traditional approaches. 
Nowadays, companies that tend to be the market leaders still have to consider the above-mentioned elements and build their own knowledge management infrastructure. The need for new knowledge should be a strategic business priority, known and accepted by the highest management levels. In this sense, it is necessary to build an organizational culture and to develop mechanisms for the exchange of knowledge. When a framework is created that encourages the exchange of knowledge and it is necessary to analyze and determine the gap between the knowledge available and the necessary knowledge, and thereafter develop mechanisms and measures of knowledge evaluation and reproduction. In this sense, organizations should find methods and techniques for discovering, collecting, reproducing and supplementing knowledge. The ultimate goal is to achieve synergic effects by combining data and information processing with the help of IT technologies with the creative and innovative skills of their employees.5 In this case we can talk about "a value chain", which means the continuous transformation of raw data into information and knowledge with the ultimate goal of making quality business decisions.

\section{The Importance of Knowledge Management}

It is not necessary to emphasize in particular that today the competitive advantage of a firm depends on how successfully it uses the knowledge of its employees, and especially how quickly can learn and adopt something new. According to estimates 6 most of the knowledge, between 50 and 95\%, and those explicit and experience ones, are transmitted through direct communication. During this, a great deal of knowledge is lost, and companies generally use about $20 \%$ of their organizational knowledge. Nowadays in this ruthless competition it is important to find and retain the untapped part of knowledge in the firm and turn into intellectual capital. Collection and systematic use of knowledge to generate new ideas can be achieved by creating an appropriate environment where the use of new information and communication technologies (ICT) will greatly facilitate the overcoming of these problems.

The ability to continuously generate new ideas and create new products is a feature of successful firms. For them, novelties are part of the business strategy. They possess a suitable and "shallow" organizational structure as well as a management that encourages the novelty system. The basis for novelty and creativity is also achieved through the creation of teams composed of people with different profiles, which is also a prerequisite for creating a range of different questions and generating new ideas.

Taking into consideration that till novelty is not achievedin such a short time, it is important that management does not expect quick results but stematically run and develop policies and activities relevant to the practical implementation of knowledge management, by the following ${ }^{7}$ :

$\checkmark$ Encourage creativity, teamwork and research approaches in activities

$\checkmark$ Organization of informal events and creation of an informal working environment

$\checkmark$ Conduct meetings in which views, ideas and knowledge are exchanged

$\checkmark$ Organize discussions and workshops

$\checkmark$ Implement benchmarking techniques of comparison, brainstorming and other methods

$\checkmark$ Investment in research and development studies

$\checkmark$ Regular analysis of business processes

$\checkmark$ Independent development of new knowledge, but also purchasing of knowledge

$\checkmark$ Organization of trainings and other forms of employee education

$\checkmark \quad$ Creating project documentation

$\checkmark \quad$ Learning from completed projects

$\checkmark$ Implement cost-benefit analysis of projects

$\checkmark$ Use knowledge outside the organization (books, studies, scientific institutions)

$\checkmark$ Collecting, storing and analyzing information for customers, suppliers and partners

$\checkmark$ Development of entrepreneurial organizational culture

$\checkmark$ Motivating employees through bonuses, funds, etc.

$\checkmark$ Development of appropriate technological infrastructure

$\checkmark$ Information system of knowledge using Intranet and the Internet

$\checkmark$ Use of BI technology.

\footnotetext{
${ }^{5}$ www.brint.com/casestudies.html, "Knowledge in Action: Case Studies (Worldwide"), 08.09.2003.

${ }^{6}$ Spremić, M., "Upravljanje znanjem od teoretskog modela do praktičnog pristupa", Računovodstvo, revizija i financije, br. 9/2001, f. 131 .

${ }^{7}$ Spremić, M., citation 6., $f 132$.
} 


\section{Intellectual Capital}

Knowledge Management is a business discipline or theory that is reflected in increasing the importance of knowledge. Their systematiccollect and use can be achieved by creating an appropriate environment that encourages the sharing and transfer of knowledge and the creation of new types of corporate property and intellectual capital. The main values of the industrial economy have been material resources, such as machines, natural resources (mining, oil) and the physical work of people. However, in today's products, apart from materials and energy, knowledge is increasingly involved (examples are today's automotive which are "fully" electronic), so the knowledge and intelligence implemented in them determines their highest or lowest prize. The value that is implemented in those products is not affected (non-material), thatis consisted of intellectual capital and not physical capital.

While the physical and financial capital are the main features of the industrial economy, in the modern business world as a new source of value is what is dynamic, mobile, convenient and intangible. In today's economy, capital is intangibile and consists of the image / brand, product brands, traditions, customer relations, relationships with partners, experiences and skills in the activity as well as the knowledge and skills of employees. These indicators that represent intangible capital generate far more new values than traditional tangible indicators. Employee knowledge, their business experience, ideas, innovations, motivation, teamwork enriches corporate culture and improves processes within the firm and enables the creation of more new knowledge compared to business costs. Thus, the most valuable share of modern capital firms often becomes tangible and "invisible" for traditional accounting measurements. The hidden and intangible property is a significant part of the value of modern firms. However, it is difficult to see and measure, so very often many firms do not pay attention to this part of the value. In the accounting sense, this part of the value equals the change in the market value and the book value at the moment of purchase (goodwill).

Although standard measurement methods can not yet be adapted to the new situations created, modern companies try to link the knowledge of employees to the financial results of the firm. With this we come to the notion of intellectual capital, which has to do with the general intellectual property and with the overall potential that the firm possesses for the creation of new values. It is the accumulated knowledge that an organization possesses to its own people. Methods, patents, designs and there is a much wider notion than wisdom8. Knowledge and intellectual capital are the permanent resources to provide competitive advantages in the contemporary business environment.

Strategic orientation and growing business globalization separate intellectual capital as a factor in competitive firms' separation. Intellectual capital can be divided into three segments: human capital, structural capital and clients' capital ${ }^{9}$.

Human capital presents the knowledge, intelligence and accumulated experience of employees. Except knowledge, it includes motivation, readiness for teamwork, co-operation, and willingnessto take risks and adaptability against change, but also loyalty to the firm. It represents knowledge, intelligence and accumulated experience of employees. It can be divided into innovative and managerial capital. Innovative capital is the driving force of creating new values and creating the competitive advantages of the organization. If the organization does not possess, the chances are very low to survive in the coming times.

Structural or organizational capital is the ability of an organization to utilize the new intellectual potential of its employees. It is commonly operationalized through the IT system, software, skills and experiences that the organization implements in processes and systems. Structural capital is what remains in the organization when its employees abandon their jobs after working hours. This is a recipe of knowledge that someone else can add to the value for the benefit of the organization.

Clients' capital is created with the synergies of firms with their environment, mainly by cultivating relationships with customers and suppliers. As mentioned above, intellectual capital is a combination of human capital - the intellect, skills, knowledge and potential of organization members and the structural capital, namely the objects representing clients, processes, databases, brands of products and technology information. This is the probability that knowledge and abstract assets become wealthy resources by multiplying human capital with structural capital ${ }^{10}$.

\footnotetext{
${ }^{8}$ Srića, V., Spremić, M., "Informacijskom tehnologijom do poslovnog uspjeha", Sinergija, Zagreb, 2000., f. 194.

${ }^{9}$ Spremić, M. "Znanje i intelektualni kapital - skrivena vrijednost kompanije", Računovodstvo i financije br. 8, $2001 ., f .17$

${ }^{10}$ Edvinsson, Leif "Korporacijska longituda - Navigacija ekonomijom znanja", Differo, Zagreb, 2003., f. 35
} 


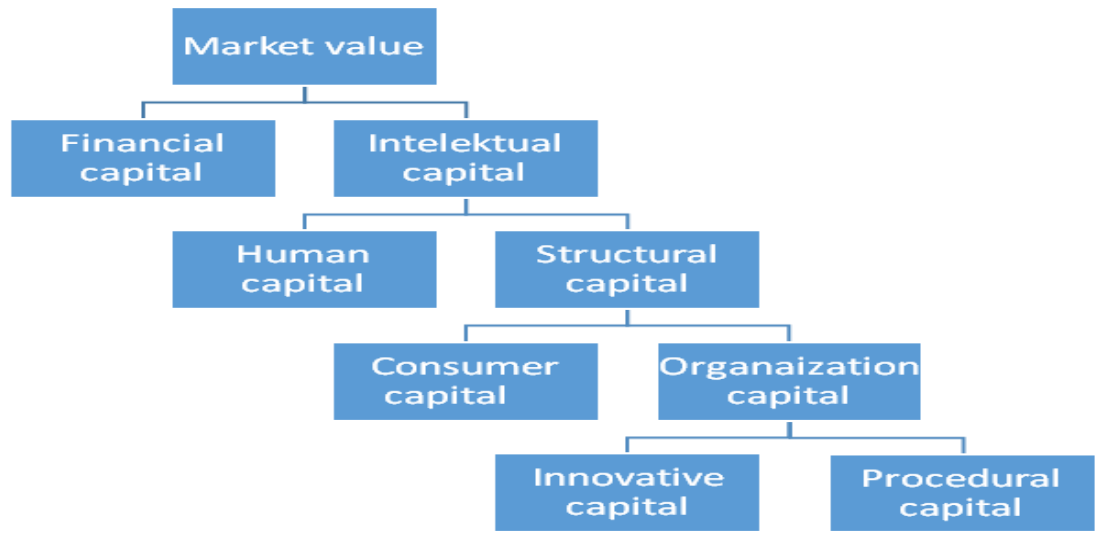

Figure 4. Evaluation scheme of intellectual capital

Although knowledge about the existence and importance of intellectual capital is increasing every day, it still represents an indispensable element for most firms. The Swedish Financial Enterprise, Skandia, in its financial reports for a long time reports on the intellectual capital of a firm, in order to inform its investors about the potential and power of the company to which it deserves knowledge, experience, innovation and other qualities of its employees. The first annual report on intellectual capital was created in 1994 and published inside the firm, then in 1995 it was first made public. That's why the firm has developed an evaluation scheme "Skandijan IC Navigator", which consists of five areas that create values. Each area focuses on a certain range of interests: financial focus, customer focus, focus of the process, focus on employees, renewals and the development of focus and context of the environment. Figure 3 presents the intellectual capital assessment scheme in a financial firm 11 . While traditional financial reports are a measure of financial success in the past, the greatest potential for adding new value is precisely in the current and the future. These are time dimensions that "flee" with traditional methods of assessment and here is the essence of the presentation of intellectual capital. Therefore, the main task of the concept of intellectual capital is to show the nature of the differences between the market value and the firm's accounting value in the market. The intellectual capital meets the standard accounting ratios. It is characteristic for them as they show business outcomes of the firm in the past period, which poses a certain risk to investors because they can only rely on previous indicators and expectations that do not necessarily reflect the real opportunities and chances of the firm. On the other hand, intellectual capital indicators point to the ability of firms to create new value and profit in the coming period and effectively complement the existing financial ratios. Figure 5 shows the model of intellectual capital measurement, which consists of five factors: financial ones, consumers, human capital, processes, development, and research.

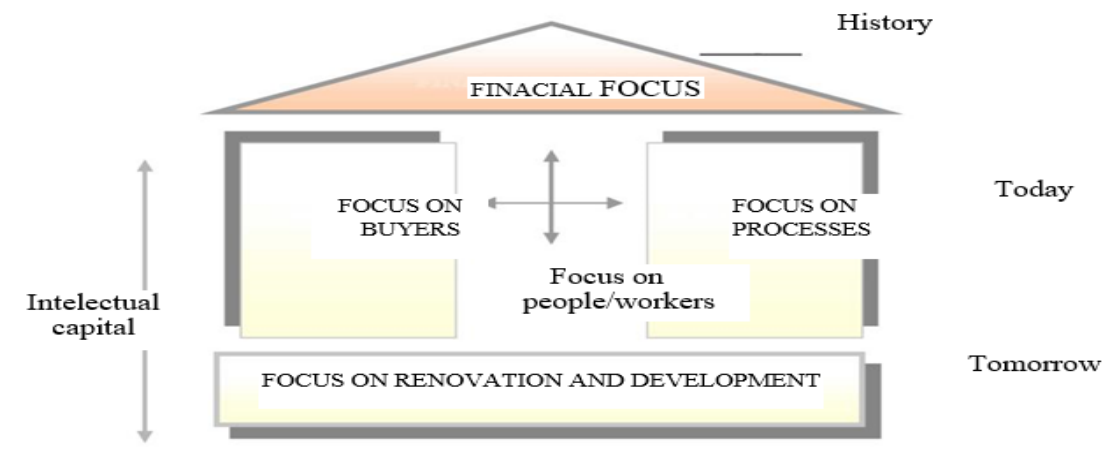

Figure 5. Intellectual capital management

\footnotetext{
${ }^{11}$ Edvinsson, L., "Korporacijska longituda - Navigacija ekonomijom znanja", Differo, Zagreb, 2003., f. 127.
} 


\section{CONCLUSIONS}

\section{Focus on Renovation and Development}

The application of new business models requires change in the application of intellectual knowledge and capital. The dynamics of today's business activity let many managers as observers because they are not able to follow new trends. They work according to the established permanent rules that are characteristic for the period of the industrial economy, and the main indicators have tons of sales, increased sales percentage, market share and more. Qualitative indicators, the well-being of employees, the efficiency of the process and the possibility of advancement to them are not a priority. Such behavior is characteristic, especially for a large number of local managers who are overwhelmed with current activity and thus let the role and the need for advancement and development of intellectual capital. Unlike the Kosovo situation, managers of developed economies spend a lot of time in learning while rates range from 15 to 30 and $40 \%$, which is typical for Japanese managers. Identifying the importance of learning and development impact the ability of managers to quickly identify cases and get ready to cope with the risks that innovations bring. Of course, reward is success and quality, which is also based on quantitative business indicators. At the end of this chapter it can be concluded that in the market turbulence conditions in which firms operate, with constant changes in their environment, relying on internal resources, in this case the knowledge of the employees themselves is the basis of the deployment of a strategy that requires constant innovations and the introduction of new products and creating new needs for buyers. Thus, they keep their leading position in the market, because with the continuous improvement of their main capabilities present new obstacles and challenges for competitors in which they are unable to respond successfully. It is certain that the coming times are based on the sharing but also on the exchange of knowledge in the market sense. The development of market mechanisms favors the creation of an efficient market knowledge that enables buyers and sellers of knowledge to exchange goods at the price determined on the basis of these markets. However, the characteristic of knowledge in contrast to other goods is that it is not consumed by use, but contrary to its value, it increases in accordance with its use.

\section{REFERENCES}

1. Leif L, (2003), "Korporacijskalongituda - Navigacijaekonomijomznanja", Differo, Zagreb;

2. Frappaolo C, (2002), "Knowledge management", Capstone Publishing, Oxford UK;

3. Srića, V (1999), "Menedžerskainformatika", M.E.P. Consult, Zagreb;

4. Srića, V, (2000), Spremić, M., "Informacijskomtehnologijom do poslovnoguspjeha", Sinergija, Zagreb;

5. Srića, V (2003), "Inventivnimenadžer u 100 lekcija", Delfin-Znanje, Zagreb;

6. Spremić, M. (2001), "Upravljanjeznanjemodteoretskogmodela do praktičnogpristupa";

7. Vidović, S (2003), "Upravljanjeznanjem", InfoTrend, Zagreb, br. 107;

8. http://mediaproducts.gartner.com/reprints/cognost/116968.htm.,07.11.2003. "Knowledge in Action: Case Studies (Worldwide)", http:// www. brint.com/ casestudies. html, 08.09.2003;

9. Spremić, M. " Znanje i intelektualni kapital - skrivena vrijednost kompanije", Računovodstvo i financije br. 8, 2001., f. 17;

10. Edvinsson, Leif "Korporacijska longituda - Navigacija ekonomijom znanja", Differo, Zagreb, 2003., f. 35;

11. Edvinsson, L., "Korporacijska longituda - Navigacija ekonomijom znanja", Differo, Zagreb, 2003., f. 127; 